\title{
PHYSICS AND CHEMISTRY OF DISSOLUTION ON SUBAERIALY EXPOSED SOLUBLE ROCKS BY FLOWING WATER FILMS
}

\author{
FIZIKA IN KEMIJA RAZTAPLJANJA ATMOSFERI \\ IZPOSTAVLJENIH VODOTOPNIH KAMNIN POD TANKO VODNO \\ PLASTJO
}

\author{
Wolfgang DREYBRODT ${ }^{1}$ \& Georg KAUFMANN ${ }^{2}$
}

\begin{abstract}
UDC 551.44:54.056

Wolfgang Dreybrodt \& Georg Kaufmann: Physics and chemistry of dissolution on subaerialy exposed soluble rocks by flowing water films

The basic process active in the formation of subaerial features on karst rocks is chemical dissolution of limestone or gypsum by water films flowing on the rock surface. The dissolution rates of limestone and gypsum into thin films of water in laminar flow are given by $\mathrm{F}=\alpha\left(\mathrm{c}_{\mathrm{eq}}-\mathrm{c}\right)$, where $\left(\mathrm{c}_{\mathrm{eq}}-\mathrm{c}\right)$ is the difference of the actual concentration $\mathrm{c}$ in the water film and the equilibrium concentration $\mathrm{c}_{\mathrm{eq}}$ with respect to the corresponding mineral. Whereas for gypsum $\alpha$ is determined by molecular diffusion the situation is more complex for limestone. Experiments are presented, which show that for high undersaturation, $c<0.3 c_{\text {eq }}$, the rate law is $\mathrm{F}=\alpha\left(0.3 \mathrm{c}_{\mathrm{eq}}-\mathrm{c}\right)$, and $\alpha$ becomes higher by about a factor of ten than for the rates at $c>0.3 \mathrm{c}_{\mathrm{eq}}$. These rate laws are used to calculate denudation rates on bare rock surfaces exposed to rainfall with differing intensity. The estimations are in reasonable agreement to field data. Starting from the experiments on the formation of Rillenkarren on gypsum performed by Glew and Ford (1980), we suggest a new relation between their length from the crest to the "Ausgleichsfläche" and the inclination of the rock surface. This is also applied to field data of Rillenkarren on limestone provided by J. Lundberg and A. Gines. In view of the many parameters influencing the formation of Rillenkarren these correlations can be considered as satisfactory.

Key words: karst, dissolution kinetics, Rillenkarren.
\end{abstract}

Izvleček

UDK 551.44:54.056

Wolfgang Dreybrodt \& Georg Kaufmann: Fizika in kemija raztapljanja atmosferi izpostavljenih vodotopnih kamnin pod tanko vodno plastjo

Skalne oblike na kamninah izpostavljenim atmosferi so posledica raztapljanja tankih vodnih plasti, ki tečjo po površini kamnine. Hitrost raztapljanja apnenca oz. sadre je podana $\mathrm{z}$ zakonom $\mathrm{F}=a\left(c_{\mathrm{eq}}-\mathrm{c}\right)$, kjer je $c_{\mathrm{eq}}-\mathrm{c}$ razlika med koncentracijo raztopljenih mineralov $\mathrm{v}$ vodnem filmu in ravnotežno koncentracijo glede na ustrezen mineral. Pri sadri je koeficient $\alpha$ določen $\mathrm{z}$ molekularno difuzijo. Za apnenec pa ekperimentalni podatki kažejo, da je pri močno podnasičeni raztopini $\left(c<0.3 c_{e q}\right)$ kinetični zakon podan $\mathrm{s} F=\alpha\left(0.3 c_{e}-c\right)$, pri čemer je $\alpha$ za red velikosti večji kot pri koncentracijah $\mathrm{c}>0.3 \mathrm{c}_{\mathrm{eq}}$. Kinetične zakone uporabimo pri računu denudacijske stopnje na kamnitih površinah izpostavljenim različnim intenzitetam dežja. Naše ugotovitve se ujemajo tudi eksperimentalnimi podatki. Z ozirom na študijo razvoja dežnih žlebičev, ki sta jo predstavila Glew in Ford (1980), predlagamo novo razmerje med dolžino žlebičev in naklonom površine. To razmerje uporabimo tudi na terenskih podatkih, ki sta jih pridobila J. Lundberg in A.Gines. V luči številnih parametrov, ki vplivajo na razvoj dežnih žlebičev so dobljene korelacije zadovoljive.

Ključne besede: kras, kinetika raztapljanja, dežni žlebič.

\footnotetext{
${ }^{1}$ Institute of Experimental Physics, Karst Processes Research Group, University of Bremen, D-28334 Bremen, Germany

${ }^{2}$ Fachbereich Geowissenschaften,Fachrichtung Geophysik, Haus D, Freie Universitaet Berlin, Malteserstr. 74-100, D-12249 Berlin, Germany
}

Received/Prejeto: 01.09.2007 


\section{INTRODUCTION}

Karren is the generic term for dissolution features on exposed soluble rock surfaces. Because of their variety of shapes and also their regularity karren have been a fascinating object of interest for geomorphologists. Although a large body of observations and descriptions of karren has been accumulated, knowledge on the physical and chemical processes on their formation by dissolution is scarce. In this paper we will focus on processes occurring on bare rock surfaces such as limestone or gypsum exposed to the atmosphere, and covered by flowing water films. Two basic ingredients control the dissolution process, the hydrodynamics of thin water films flowing down inclined surfaces, and the dissolution kinetics of the
$\mathrm{CO}_{2}$-containing rainwater on limestone or gypsum rock surfaces. After discussion of these two topics, we will use this for an interpretation of the data of Glew and Ford (1980), who performed experimental simulations on the formation of Rillenkarren on inclined surfaces of plaster of Paris exposed to artificial rainfall.

Using these results an interpretation of existing field data on lengths of rillenkarren is presented.

Also recent data by Petterson (2001) on dissolution on Rillenkarren from Plaster of Paris will be discussed. Finally the dissolution kinetics of limestone will be used to explain surface denudation on bare limestone surfaces.

\section{THE FLUID DYNAMICS OF WATER FILMS ON SMOOTH AND ROUGH SURFACES}

When rain with intensity q $\left(\mathrm{cms}^{-1}, 1 \mathrm{~mm} /\right.$ hour $=2.8 \cdot 10^{-5}$ $\mathrm{cms}^{-1}$ ) falls onto an inclined smooth surface with slope angle $\gamma$, a thin layer of water is established (see Fig. 1). Its flow rate $\mathrm{Q}$ in $\mathrm{cm}^{3} / \mathrm{s}$ per unit width is given in $\mathrm{cm}^{2} / \mathrm{s}$. After distance $x^{\prime}=\ell$ down the surface of the rock $Q$ is

$$
\mathrm{Q}=\mathrm{x} \cdot \mathrm{q}=\ell \mathrm{q} \cos \gamma
$$

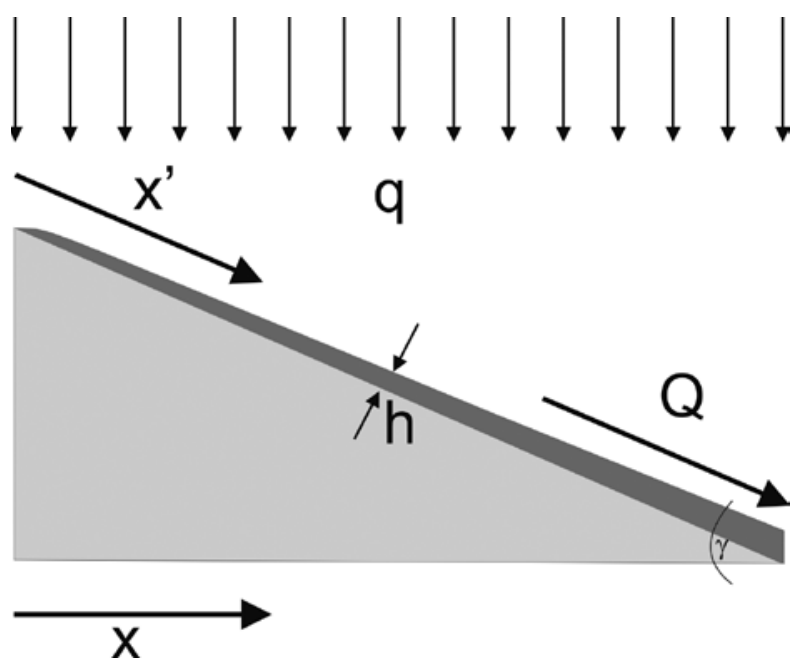

Fig. 1: Water film on inclined rock surface.

The thickness $\mathrm{h}$ (in $\mathrm{cm}$ ) of the water film is related to flow Q (Myers, 2002) by

$$
\mathrm{Q}=\frac{\rho \mathrm{gh}^{3}}{3 \eta} \sin \gamma
$$

where $\mathrm{g}$ is earth's gravitational acceleration, $\rho$ is the density of water, and $\eta$ its viscosity. By using eqns. 1 and 2 , we obtain the film thickness

$$
\mathrm{h}=\sqrt[3]{\frac{3 \eta \mathrm{q} \ell}{\rho g \tan \gamma}}
$$

For rainfall intensities of $1 \mathrm{~mm} /$ hour onto a surface sloping with $45^{\circ}$ and at a distance $\ell=50 \mathrm{~cm}$, a fairly thin film of $\mathrm{h}=3.6 \cdot 10^{-3} \mathrm{~cm}$ develops. For $40 \mathrm{~mm} /$ hour rainfall intensity as used by Glew and Ford (1980), the film thickness $\mathrm{h}$ is $1.2 \cdot 10^{-2} \mathrm{~cm}$.

The flow velocity $\mathrm{u}$ (in $\mathrm{cms}^{-1}$ ) is obtained from $\mathrm{u} \cdot \mathrm{h}=\mathrm{Q}$ by inserting eqns. 2 and 3 and one finds

$$
u=\sqrt[3]{\frac{\rho g Q^{2} \sin \gamma}{3 \eta}}=\sqrt[3]{\frac{\rho g q^{2} \ell^{2} \cos ^{2} \gamma \sin \gamma}{3 \eta}}
$$

Note that the velocity increases with flow distance $\ell$. Assuming a rainfall of $10 \mathrm{~mm} /$ hour, a flow distance of $1 \mathrm{~m}$, and a slope angle of $45^{\circ}$, the velocity is $2.1 \mathrm{cms}^{-1}$. If rainfall is reduced to $1 \mathrm{~mm} /$ hour one finds $0.5 \mathrm{cms}^{-1}$. These velocities are of importance because they give the time of residence during which a water parcel can dissolve bedrock.

When the surface is rough a correction factor must be introduced (Myers, 2002), which is given by

$$
\mathrm{f}_{\mathrm{c}}=\left[1-0.25\left(\frac{\mathrm{k}}{\mathrm{h}}\right)^{1.28}\right]
$$


where $\mathrm{k}$ is the roughness of the surface and $\mathrm{h}$ the film thickness of the layer on a smooth surface, as given by eqn. 3 (Phelps, 1975). This dimensionless factor relates the flow velocities $u$ and $u_{r}$ of the smooth to the rough surfaces respectively.

$$
u_{r}=f_{c} \cdot u
$$

Because $\mathrm{u} \cdot \mathrm{h}=\mathrm{Q}$ the film thickness values are related by

$$
\mathrm{h}_{\mathrm{r}}=\frac{1}{\mathrm{f}_{\mathrm{c}}} \mathrm{h}
$$

For $\mathrm{k} / \mathrm{h}=2$, a reasonable number, we obtain $\mathrm{fc} \approx 0.4$, and flow velocities are lower. Film thickness values are higher by a factor of 2.5 .

\section{DISSOLUTION KINETICS}

\section{GYPSUM}

By use of rotating disc experiments Jeschke et al., (2001) have found that the surface reaction rates of gypsum (in $\mathrm{mmol} \mathrm{cm} \mathrm{cs}^{-2} \mathrm{~s}^{-1}$ are given by

$$
\mathrm{R}_{\mathrm{s}}=\mathrm{k}_{\mathrm{s}}\left(1-\mathrm{c}_{\mathrm{s}} / \mathrm{c}_{\mathrm{eq}}\right)=\alpha_{\mathrm{s}}\left(\mathrm{c}_{\mathrm{eq}}-\mathrm{c}_{\mathrm{s}}\right)
$$

with $\alpha_{\mathrm{s}}=\mathrm{k}_{\mathrm{s}} / \mathrm{c}_{\mathrm{eq}}$

Here, $c_{s}$ is the calcium-concentration at the surface and the rate constant is $\mathrm{k}_{\mathrm{s}}=1.1 \cdot 10^{-4} \mathrm{mmol} \mathrm{cm}^{-2} \mathrm{~s}^{-1}$. The equilibrium concentration $\mathrm{c}_{\mathrm{eq}}$ with respect to gypsum is $15,4 \cdot 10^{-3} \mathrm{mmol} \mathrm{cm}^{-3} \cdot \mathrm{Ca}^{2+}$ and $\mathrm{SO}_{4}^{2-}$-ions released from the mineral surface are transported away from the surface into the solution by molecular diffusion. Therefore concentration gradients exist and the surface concentration cs differs from the concentration $c$ in the bulk. The transport rate $\mathrm{R}_{\mathrm{D}}$ by molecular diffusion is given by

$$
\mathrm{R}_{\mathrm{D}}=\mathrm{k}_{\mathrm{D}}\left(1-\mathrm{c} / \mathrm{c}_{\mathrm{eq}}\right)=\alpha_{\mathrm{D}}\left(\mathrm{c}_{\mathrm{eq}}-\mathrm{c}\right)
$$

with $\alpha_{\mathrm{D}}=\mathrm{k}_{\mathrm{D}} / \mathrm{c}_{\mathrm{eq}}$,

where $\mathrm{k}_{\mathrm{D}}$ is the transport constant and $\mathrm{c}$ is the average concentration of the bulk solution. Since due to mass conservation $R_{S}$ must be equal to $R_{D}$, one finds an effective rate law (Dreybrodt, 1988).

$$
\begin{aligned}
& \mathrm{R}=\mathrm{k}_{\mathrm{eff}}\left(1-\mathrm{c} / \mathrm{c}_{\mathrm{eq}}\right) \text { with } \mathrm{k}_{\text {eff }}=\frac{\mathrm{k}_{\mathrm{s}} \cdot \mathrm{k}_{\mathrm{D}}}{\mathrm{k}_{\mathrm{s}}+\mathrm{k}_{\mathrm{D}}} \\
& \text { or } \mathrm{R}=\alpha_{\text {eff }}\left(\mathrm{c}_{\mathrm{eq}}-\mathrm{c}\right) \text { with } \alpha_{\text {eff }}=\frac{\alpha_{\mathrm{s}} \cdot \alpha_{\mathrm{D}}}{\alpha_{\mathrm{s}}+\alpha_{\mathrm{D}}}
\end{aligned}
$$

When $\mathrm{k}_{\mathrm{s}}>>\mathrm{k}_{\mathrm{D}}, \mathrm{k}_{\mathrm{eff}}$ becomes close to $\mathrm{k}_{\mathrm{D}}$ and rates are controlled by diffusion. On the other hand if $\mathrm{k}_{\mathrm{s}}<<\mathrm{k}_{\mathrm{D}}, \mathrm{k}_{\text {eff }}$ becomes close to ks and the rates are surface controlled. In the region where $\mathrm{ks}$ and $\mathrm{k}_{\mathrm{D}}$ are of similar magnitudes both processes control dissolution.
For a laminar water film of thickness $\mathrm{h}$, the transport coefficient $\mathrm{k}_{\mathrm{D}}$ is given by (Beek \& Muttzall, 1975)

$$
\mathrm{k}_{\mathrm{D}}=2 \mathrm{Dc}_{\mathrm{eq}} / \mathrm{h}, \text { or } \alpha_{\mathrm{D}}=2 \mathrm{D} / \mathrm{h},
$$

where $\mathrm{D}$ is the coefficient of diffusion $\left(1 \cdot 10^{-5} \mathrm{~cm}^{-2} \mathrm{~s}^{-1}\right)$. For $\mathrm{h}=0.01 \mathrm{~cm}$ one obtains $\alpha_{D}=1 \cdot 10^{-3} \mathrm{~cm}^{-1}$ and the rates are controlled by diffusion. However, raindrops impinging on the water film may cause mixing, which could increase the effective diffusion constant. Only a factor of 10 suffices to obtain surface control and a value of $\mathrm{a}_{\text {eff }} \approx 7 \cdot 10^{-3}$ $\mathrm{cms}^{-1}$.

To convert the rates from $\mathrm{mmol} \mathrm{cm} \mathrm{cs}^{-1}$ into retreat of rock in $\mathrm{cm} /$ year for gypsum one has to multiply by a factor of $2.3 \cdot 10^{6}$.

\section{LIMESTONE}

Water films running down rock surfaces under natural rainfall conditions have a comparatively small depth of a few tenths of a millimetre. In contrast to gypsum, where dissolution rates are determined by both, surface reaction and molecular diffusion, the situation on limestone is more complex. Fig. 2 schematically depicts three regimes of dissolution rates. For highly undersaturated solutions, $0<\mathrm{c} \leq \mathrm{c}_{\text {app }}$, rates are high and decline steeply with slope $\alpha_{1}$ to an apparent equilibrium concentration $c_{\text {app }}=0.3 \cdot c_{\text {eq }}$, where $c_{e q}$ is the true equilibrium concentration with respect to calcite. The values of $\alpha_{1}$ are almost independent on the film thickness $\mathrm{h}$ for $0.005 \mathrm{~cm}<\mathrm{h}<0.03 \mathrm{~cm}$, and $\alpha_{1}=5 \cdot 10^{-4} \mathrm{cms}^{-1}$, (Kaufmann and Dreybrodt, 2007).

To a good approximation the rates found by theoretical modelling can be expressed (Kaufmann, 2004) by

$$
\mathrm{R}_{\mathrm{I}}=\alpha_{1}\left(\mathrm{c}_{\mathrm{app}}-\mathrm{c}\right) \text { for } \mathrm{c} \leq 0.3 \mathrm{c}_{\mathrm{eq}} \text {. }
$$

For higher calcium concentrations a second linear region with significantly lower slope $\alpha_{2}$ arises, until close to equilibrium in region 3 for $c \geq c_{s w}$, above the switch concentration $c_{\text {sw }}=0.9 c_{\text {eq }}$ inhibition occurs and the rates are controlled by slow surface reactions. 


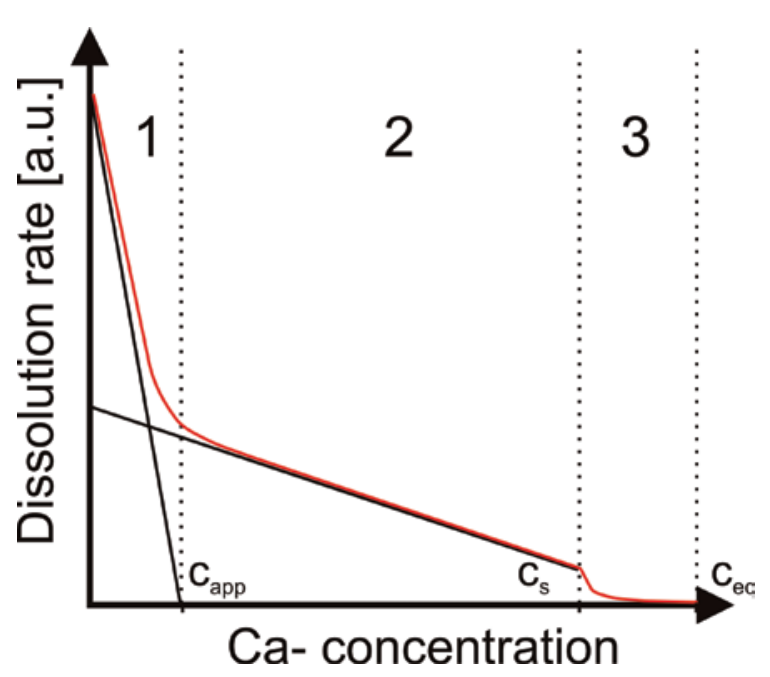

Fig. 2: Dissolution rates of limestone by $\mathrm{CO}_{2}$-containing water. Three regimes of very fast (Region 1), moderate (Region 2), and inhibited dissolution rates (region 3) are clearly distinguishable. Only the fast dissolution rate in region 1 is relevant in this paper.

The dissolution rates in regions 2 and 3 are well understood (Plummer et al., 1978; Buhmann and Dreybrodt, 1985; Svensson and Dreybrodt, 1992).

Three basic chemical reactions control the dissolution of $\mathrm{CaCO}_{3}$

1. $\mathrm{H}^{+}+\mathrm{CaCO}_{3} \underset{\leftarrow}{\leftarrow} \mathrm{Ca}^{2+}+\mathrm{HCO}_{3}^{-}$

2. $\mathrm{H}_{2} \mathrm{CO}_{3}+\mathrm{CaCO}_{3} \underset{\leftarrow}{\leftarrow} \mathrm{Ca}^{2+}+2 \mathrm{HCO}_{3}^{-}$

3. $\mathrm{CaCO}_{3}+\mathrm{H}_{2} \mathrm{O}_{\rightarrow}^{\leftarrow} \mathrm{Ca}^{2+}+\mathrm{CO}_{3}^{2-}+\mathrm{H}_{2} \mathrm{O}_{\rightarrow}^{\leftarrow} \mathrm{Ca}^{2+}+$ $+\mathrm{HCO}_{3}^{-}+\mathrm{OH}^{-}$

For all three reactions $\mathrm{CO}_{2}$ dissolved in the solution must be hydrated into carbonic acid, which rapidly reacts to $\mathrm{H}^{+}+\mathrm{HCO}_{3}^{-}$.

$$
\text { 4. } \mathrm{H}_{2} \mathrm{O}+\mathrm{CO}_{2} \stackrel{\leftarrow}{\leftarrow} \mathrm{H}_{2} \mathrm{CO}_{3}
$$

5. $\mathrm{CO}_{2}+\mathrm{OH}^{-} \stackrel{\leftarrow}{\rightarrow} \mathrm{HCO}_{3}^{-}$

The $\mathrm{pH}$-values of the solution in region 2 are between 7.5 and 8.3. For such $\mathrm{pH}$-values conversion of $\mathrm{CO}_{2}$ is slow (Usdowski 1982, Dreybrodt 1988) and for thin films below $0.02 \mathrm{~cm}$ control by $\mathrm{CO}_{2}$-conversion limits the rates. For film thickness between $0.01 \mathrm{~cm}$ up to $0.04 \mathrm{~cm}$ slope values are about $\alpha_{2} \approx 3 \cdot 10^{-5} \mathrm{cms}^{-1}$, lower by about one order of magnitude than $\alpha_{1}=5 \cdot 10^{-4} \mathrm{cms}^{-1}$.

The reason for the high rates in region 1 are reactions (1) and (3). When no calcite has yet been dissolved the initial $\mathrm{pH}$ of the solution in equilibrium with $\mathrm{CO}_{2}$ in the atmosphere is 5.7. Since reaction (1) is very fast protons are rapidly consumed by dissolving calcite.

Furthermore dissolution of calcite produces $\mathrm{OH}^{-}$ ions. Therefore $\mathrm{pH}$ increases to values of about 11 . Because of the high concentration of $\mathrm{OH}^{-}$, conversion of $\mathrm{CO}_{2}$ is fast by reaction 5 . With increasing Ca-concentration $\mathrm{pH}$ drops, and consequently slow conversion of $\mathrm{CO}_{2}$ by reaction (4) takes over in controlling the rates. As a conclusion we state that for low concentrations $\mathrm{c}$ the rates are given by the relation

$$
\begin{aligned}
& \mathrm{R}=\alpha_{1}\left(0.3 \mathrm{c}_{\text {eq }}-\mathrm{c}\right) ; \quad 0<\mathrm{c}<0.3 \mathrm{c}_{\text {eq }} \\
& \mathrm{R}=\alpha_{2}\left(\mathrm{c}_{\text {eq }}-\mathrm{c}\right) ; \quad \mathrm{c}>0.36<0.9 \mathrm{c}_{\text {eq }}
\end{aligned}
$$

\section{EXPERIMENTAL DETERMINATION OF DISSOLUTION RATES IN REGION 1}

When a thin water layer of width $\mathrm{W}$ flows down a smooth, plane limestone surface with inclination angle $\gamma$ it dissolves calcite and the concentration $\mathrm{c}(\mathrm{x})$ of calcium along its flow path increases. Note that in this section for simplicity we use $\mathrm{x}$ instead of $\mathrm{x}$ ' for the flow path on the rock surface. The amount of calcite dissolved during one second between positions $\mathrm{x}$ and $\mathrm{x}+\mathrm{dx}$ is given by $\alpha_{1}\left(\mathrm{c}_{\mathrm{app}}-\right.$ $\mathrm{c}(\mathrm{x})) \cdot \mathrm{dx} \cdot \mathrm{W}$. Due to mass conservation this must be equal with $Q_{\text {total }} d c$, where $d c$ is the increase in concentration from $x$ to $x+d x$, and $Q_{\text {total }}$ is the total flow rate in $\mathrm{cm}^{3} \mathrm{~s}^{-1}$. From this a differential equation is found

$$
\frac{\mathrm{dc}}{\mathrm{dx}}=\frac{\alpha_{1} \cdot \mathrm{W}}{\mathrm{Q}_{\text {total }}}\left(\mathrm{c}_{\mathrm{app}}-\mathrm{c}\right)
$$

Its solution is

$$
\mathrm{c}(\mathrm{x})=\mathrm{c}_{\text {app }}\left(1-\exp \left(-\frac{\alpha_{1}}{\mathrm{Q}} \mathrm{x}\right)\right)
$$

where $\mathrm{Q}=\mathrm{Q}_{\text {total }} / \mathrm{W}$ is the amount of flow in one $\mathrm{cm}$ width of the film.

We use eqn. 16 to determine $\alpha_{1}$ experimentally. To this end, we have constructed a channel of $5 \mathrm{~cm}$ width and $1.2 \mathrm{~m}$ length by employing acryl rims fixed to a plate of limestone. The inclination is $\gamma=3.2^{\circ}$. At the end of the channel a funnel of acryl-glass channels the water into a hole from where it runs into a bottle. The experiment is illustrated in Fig. 3a, which provides a view from above. To guide the water into a stable film the channel at its upper end is blocked by a piece of acryl-glass, which leaves a narrow space of a few tenths of a millimetre between the limestone surface and its lower plane face (see Fig. $3 b$ ). Distilled water in equilibrium with the $\mathrm{p}_{\mathrm{CO}_{2}}$ in the atmosphere by use of a peristaltic pump is introduced into 


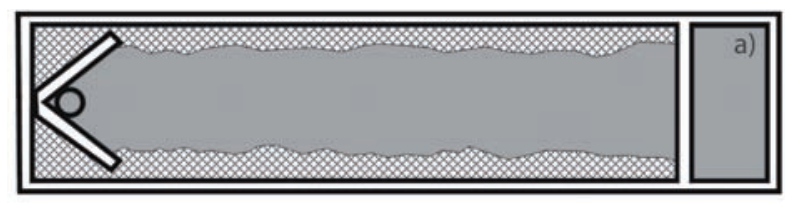

b)

To peristaltic pump

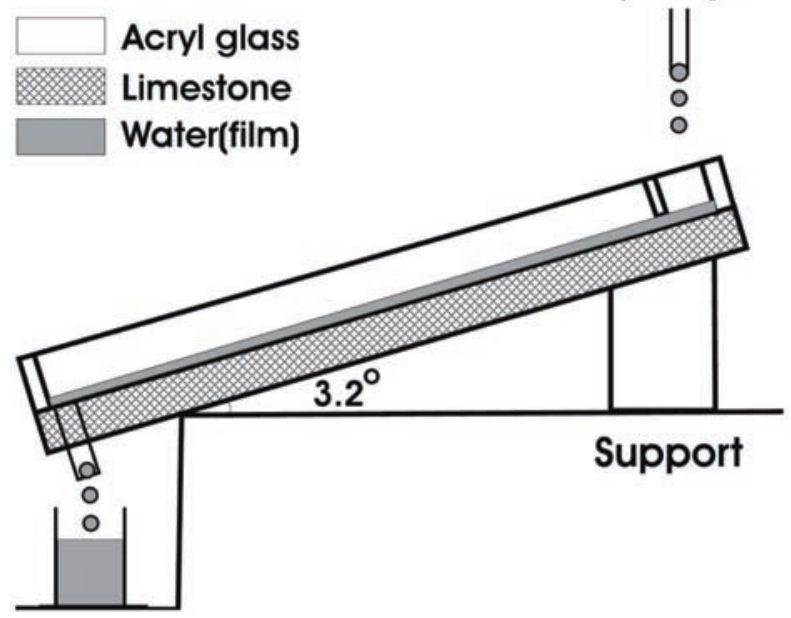

Fig. 3: Experimental set up to measure limestone dissolution rates in Region 1 (top and side view). Length $\ell$ of channel $120 \mathrm{~cm}$, width of channel $5 \mathrm{~cm}$, average width $W$ of water film $4 \mathrm{~cm}$.

the upper compartment, and a film of constant thickness moves down in laminar flow at ambient temperature of $20^{\circ} \mathrm{C}$. This film is established by drawing down the water along the limestone surface by use of a wet paper strip as wide as the film is desired to be. The water film does not touch the acryl walls but is kept by surface tension. It does not change its shape, even when its depth varies by a factor of three. The surface of the film is absolutely plain as can be seen by a mirror like reflection of light. The flow rate $\mathrm{Q}$ is measured by collecting $10 \mathrm{ml}$ of water at the outlet hole at the end of the channel, and measuring the time needed. The calcium concentration $\mathrm{c}_{\text {end }}$ of this sample is then measured for various values of Q. Furthermore wa-

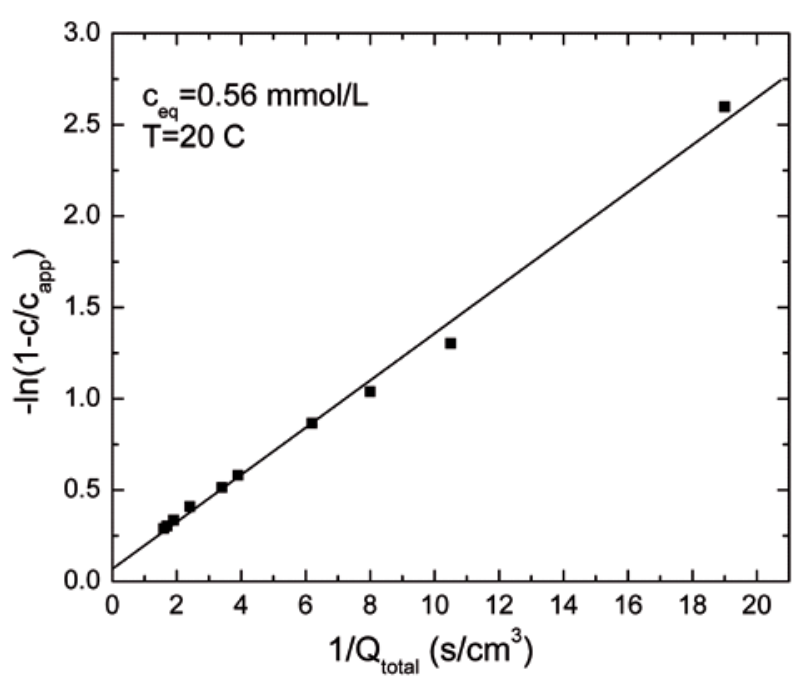

Fig. 4: Calcium concentration versus inverse of flow rate for experimental data (squares). $Q_{\text {total }}$ is the total flow rate of the film. The straight line is a least square fit to the data.

ter in equilibrium with atmospheric $\mathrm{p}_{\mathrm{CO}_{2}}$ and calcite is used to measure $\mathrm{c}_{\mathrm{eq}}$. The calcium concentrations are determined by measuring electrical conductivity, which for such low concentrations is linear with calcium concentration. The experiment was performed at $25 \mathrm{C}$.

Eqn. 16 can be rewritten to

$$
-\ell \mathrm{n}\left(1-\frac{\mathrm{c}_{\text {end }}}{\mathrm{c}_{\mathrm{app}}}\right)=\frac{\alpha_{1} \cdot \ell \cdot \mathrm{W}}{\mathrm{Q}_{\text {total }}}
$$

Fig. 4 shows the plot of the experimental data in terms of ${ }^{-} \ln \left(1-\frac{\mathrm{c}_{\text {end }}}{\mathrm{c}_{\text {app }}}\right)$ versus $1 / \mathrm{Q}_{\text {total }}$. This can be fitted with a straight line by using $c_{\text {app }}=0.3 c_{\text {eq }}=0.17 \mathrm{mmol} / \mathrm{cm}^{3}$. From the slope 0.129 of the line one finds $\alpha_{1}=2.6 \cdot 10^{-4}$ $\mathrm{cms}^{-1}$, which is in reasonable agreement to the theoretical predictions of $\alpha_{1}^{\text {th }}=5 \cdot 10^{-4} \mathrm{cms}^{-1}$ and $\mathrm{c}_{\text {app }}^{\text {th }}=0.36 \mathrm{c}_{\mathrm{eq}}$.

\section{SOLUTION ON BARE ROCK SURFACES}

When rain falls onto an inclined surface the flow rate downstream increases (see Fig. 1). If at $x^{\prime}=0$ the flow rate is $\mathrm{Q}_{0}$; then at a later position $\mathrm{x}^{\prime}$ it is given by

$$
\mathrm{Q}=\mathrm{Q}_{0}+\mathrm{q}^{\prime} \mathrm{x}^{\prime} \cos \gamma=\mathrm{Q}_{0}+\mathrm{q}^{\prime} \mathrm{x}^{\prime}
$$

Mass conservation demands that

$$
\begin{aligned}
& W\left(Q_{0}+q^{\prime} x^{\prime}\right) c+W \tilde{\alpha} \cdot\left(c_{e q}-c\right) d x^{\prime}= \\
& =W\left(Q_{0}+q^{\prime} x^{\prime}+q^{\prime} d x^{\prime}\right)(c+d c)
\end{aligned}
$$

where $c$ is the average concentration at position $\mathrm{x}$, and $W$ is the width of the film. $\tilde{\alpha} \approx \alpha \cdot f_{\alpha}$, where $f_{\alpha}$ is a correction factor considering the roughness of the rock sur- 
face. If one assumes that the rock surface consists of small half spheres densely packed, instead of a smooth plane, the surface area available for dissolution will increase by $\mathrm{f}_{\alpha}=2$. This gives an estimation on the order of magnitude of $\mathrm{f}_{\alpha}$. Equation 19 states that the outflow of calcium at position $\mathrm{x}^{\prime}+\mathrm{dx}$ ' is given by the inflow at position $\mathrm{x}^{\prime}$ plus the amount of calcium ions dissolved per time between $x^{\prime}$ and $x^{\prime}+d x^{\prime}$. Neglecting terms with dx'dc one finds a differential equation.

$$
\frac{d x^{\prime}}{Q_{0}+q^{\prime} x^{\prime}}=\frac{d c}{\tilde{\alpha}\left(c_{\text {eq }}-c\right)-q^{\prime} c}
$$

with solution

$$
c\left(x^{\prime}\right)=\frac{\tilde{\alpha} c_{e q}}{q^{\prime}+\tilde{\alpha}}\left[1-\left(1+\frac{q^{\prime} x^{\prime}}{Q_{0}}\right)^{-\frac{q^{\prime}}{q^{\prime}+\tilde{\alpha}}}\right]
$$

For large values of $x^{\prime}$ the concentration approaches the value

$$
c_{\infty}=\frac{\tilde{\alpha}}{q^{\prime}+\tilde{\alpha}} c_{e q}
$$

$90 \%$ of this value is reached at a distance

$$
\mathrm{x}_{0.9}^{\prime}=\frac{\mathrm{Q}_{0}}{\mathrm{q}^{\prime}}\left[(10)^{+\frac{\mathrm{q}^{\prime}}{\mathrm{q}^{\prime}+\tilde{\alpha}}}-1\right]
$$

For $\mathrm{Q}_{0}=0$ the concentration $\mathrm{c}_{\infty}$ is established immediately. Therefore dissolution rates are uniform downstream if one assumes that $\tilde{\alpha}$ is independent of the thickness of the water sheet. This is not true for gypsum. A reasonable approximation is to use average values. For gypsum $\alpha$ is maximal $7.1 \cdot 10^{-3} \mathrm{cms}^{-1}$ if the rates are controlled by surface reactions and at a sheet thickness of 0.1 $\mathrm{mm}$ it is $1.56 \cdot 10^{-3} \mathrm{cms}^{-1}$ (see eqn. 10 ). At a sheet thickness of $0.5 \mathrm{~mm}$ one finds $\alpha=3.8 \cdot 10^{-4} \mathrm{cms}^{-1}$.

\section{RILLENKARREN}

\section{EXPERIMENTS ON FORMATION OF RILLENKARREN ON GYPSUM}

Glew and Ford (1980) experimentally simulated the formation of Rillenkarren on gypsum by exposing inclined surfaces of plaster of Paris to a rainfall intensity of 38 $\mathrm{mm} /$ hour, which lasted for $500 \mathrm{~h}$. They obtained well developed Rillenkarren. Their average length from the crest to the "Ausgleichsfläche" was dependent on the angle of inclination, as shown in Fig. 5. Ford and Glew argued, that the "Ausgleichsfläche" could form only when the water film exceeds a critical thickness $h_{c}$, which should be higher than the roughness $\mathrm{k}$ of the rock. With this assumption by use of eqns. 1 and 2 one finds

$$
\ell=\frac{\rho g}{3 \eta q} h_{c}^{3} \tan \gamma
$$

Therefore, by plotting $\ell$ versus tan $\gamma$ one should find a straight line. This indeed is the case for the Glew \& Ford (1980) data, as shown by Fig. 5. The slope of this line is 14 $\mathrm{cm}$, from which one finds a critical thickness $h_{c}=7.7 \cdot 10^{-3} \mathrm{~cm}$ if one assumes a smooth surface. For a rough surface with $\mathrm{k}=\mathrm{h}_{\mathrm{c}}$ one finds a value of $10^{-2} \mathrm{~cm}$. Glew and Ford measured a value below $(1.5 \pm 0.5) \cdot 10^{-2} \mathrm{~cm}$, which is in good agreement. They also measured dissolution rates of $4 \cdot 10^{-3}$ $\mathrm{cm} / \mathrm{h}$. For their experimental data one finds $\mathrm{c}_{\infty} \approx 0.66 \mathrm{c}_{\text {eq }}$ from eqn. 17.

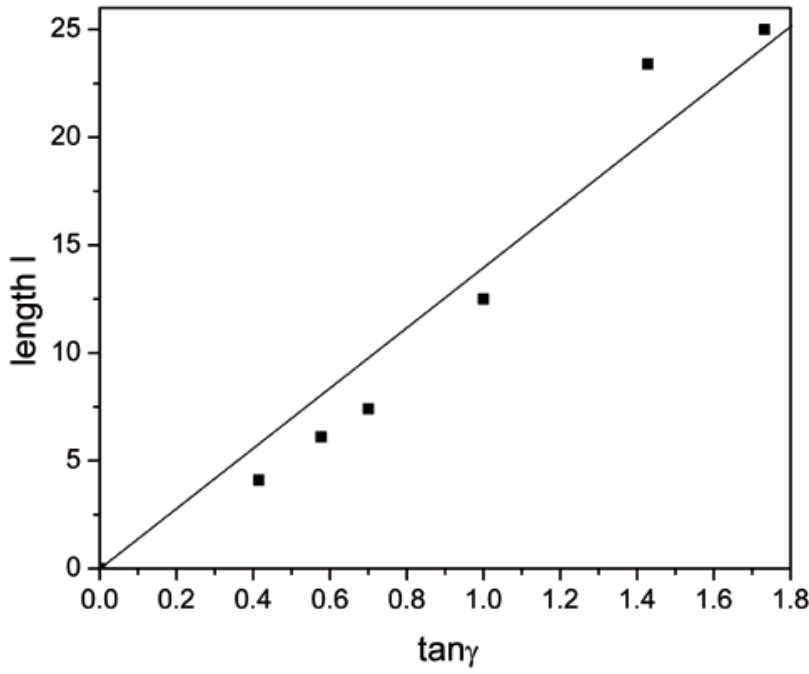

Fig. 5: Length of experimental rillenkarren versus slope, tan $\gamma$. The squares are experimental data from Glew and Ford (1980). The line represents eqn. 24 with $h c=7.7 \cdot 10^{-3} \mathrm{~cm}$

The amount of flow leaving a rock of width $\mathrm{W}$ at $\mathrm{x}$ is equal to the amount of rainfall which falls to the area $\mathrm{W} \cdot \mathrm{x}$. It carries away the mass of rock $\mathrm{q} \cdot \mathrm{c}_{\infty} \cdot \mathrm{x}$ which is dissolved from the rock's surface area $\mathrm{Wx}$ ' $=\mathrm{Wx} / \cos \gamma$. Converting the mass of dissolved material to its volume one finds the retreat of rock 

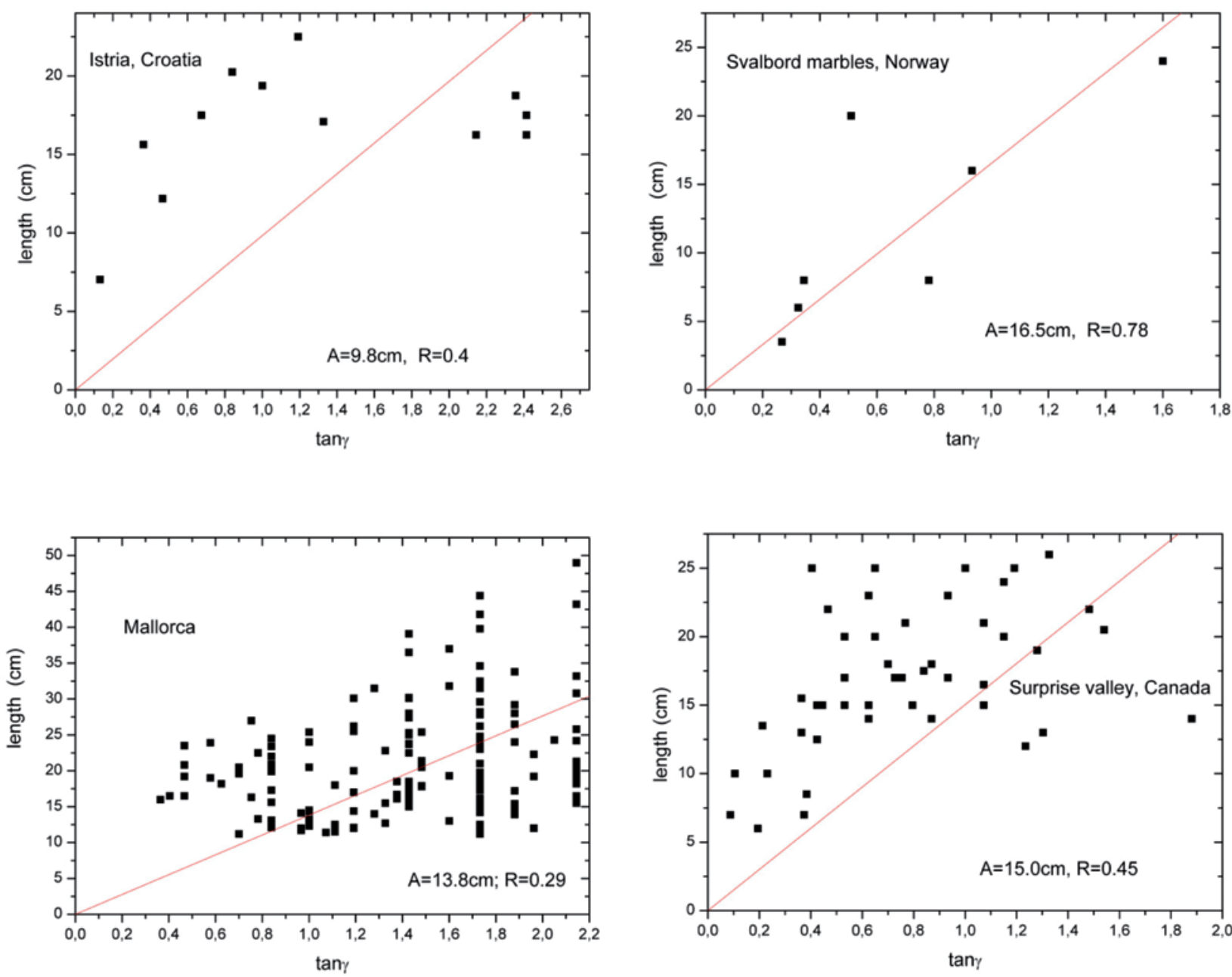

Fig. 6: Length of natural rillenkarren on limestone versus slope tan $\gamma$. From J. Lundberg and A. Gines, private communication. The straight lines are fits to $\ell=A \cdot \tan \gamma$.

$$
\mathrm{R}_{\mathrm{D}}=\mathrm{c}_{\infty} \cdot \mathrm{q} \cdot \cos \gamma / \rho_{\mathrm{g}}
$$

where $\rho_{\mathrm{g}} \mathrm{g} / \mathrm{cm}^{3}$ is the density of gypsum. With the experimental conditions of Glew and Ford one finds $R_{D}=2.7 \cdot 10$ ${ }^{3} \cdot \cos \gamma(\mathrm{cm} / \mathrm{h})$. This fits reasonably well into their data set. However, it represents a lower limit because one assumes laminar flow. Splashing raindrops may disturb this flow and cause mixing of the solution by which the effective diffusion constants increase. A factor of 10 is sufficient to rise $\mathrm{c}_{\infty}$ to $0.9 \mathrm{c}_{\mathrm{eq}}$.

In a recent work Petterson (2001) has exposed Rillenkarren channels modelled from real limestone Rillenkarren by plaster of Paris, to artificial rain of $115 \mathrm{~mm} /$ hour intensity. By using an optical technique he measured the thickness of the laminar flowing water films along the karren rills. The thickness of these films, measured at a distance of $5 \mathrm{~cm}$ to $40 \mathrm{~cm}$ from the upper edge, range from $0.2 \mathrm{~mm}$ up to $0.8 \mathrm{~mm}$, when the karren model was tilted by $30^{\circ}$. Water samples collected from the karren at various distances from the crest were used to measure the calcium concentration profile along the karren. Petterson found an almost linear increase from $75 \mathrm{mg} / \ell$ of calcium at $5 \mathrm{~cm}$ to a value of $105 \mathrm{mg} / \ell$ at $40 \mathrm{~cm}$. The average value was $90 \mathrm{mg} / \ell \pm 15 \mathrm{mg} / \ell$.

With an average film thickness of $0.5 \mathrm{~mm}$ one finds $\tilde{\alpha}=7.6 \cdot 10^{-4} \mathrm{cms}^{-1}$. With a rainfall intensity of $115 \mathrm{~mm} / \mathrm{h}=$ $3.2 \cdot 10^{-3} \mathrm{cms}^{-1}$ by use of eqn. 22 one obtains a value $c_{\infty}=118$ $\mathrm{mg} / \ell$. In view of the approximations this can be regarded as good agreement to experiment and proves our theoretical considerations.

\section{INTERPRETATION OF FIELD DATA OF RILLENKARREN}

A large body of data has been collected, which relates the lengths of Rillenkarren to the slope of the rock surface 
where they grow. From eqn. 24 one expects a linear relation of length and slope.

$$
\ell=A \cdot \tan \gamma \text { with } A=\frac{\rho g}{3 \eta q} h_{c}^{3}
$$

Fig. 6 shows average lengths of Rillenkarren versus slope $(\tan \gamma)$ for several areas (Gines and Lundberg, 2006). The straight line represents a least square fit by the relation $\ell=$ const.tan $\gamma$ to the data points with $\gamma \leq 46^{\circ}(\tan \gamma$ $\leq 2)$.

Although the scatter of points, which could be caused by differing values of precipitation $\mathrm{q}$ at different sites and times is significant one finds $A=12.6 \pm 3 \mathrm{~cm}$ for all plots. From this by use of eqn (1) one obtains $h_{c}^{3}$ / $\mathrm{q}=(3.9 \pm 0.2) \cdot 10^{-4} \mathrm{~cm}^{2} \mathrm{~s}$.

Fig. 7 shows the relationship of length with mean annual temperature as reported by Lundberg and Gines (2006). The data can be fitted by a relation $\ell=0.5 \mathrm{~T}+12.6$ $(\mathrm{cm})$, where $\mathrm{T}$ is in ${ }^{\circ} \mathrm{C}$. The variation of $\ell$ in tempera-

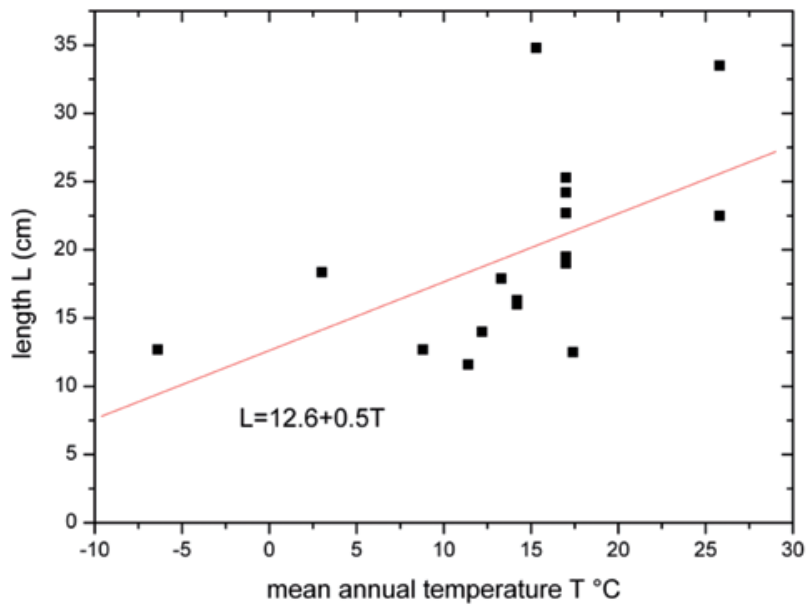

Fig. 7: Length of natural rillenkarren on limestone versus mean annual temperature. From J. Lundberg and A. Gines, private communication.

ture could result from the temperature dependence of $\eta$ which can be presented with an accuracy within $2 \%$ by the empirical relation

$$
1 / \eta=53.8+2.76 \mathrm{~T}\left(\frac{\mathrm{cm} \mathrm{s}}{\mathrm{g}}\right)
$$

Introducing this into eqn (26) one finds using $\mathrm{h}_{\mathrm{c}}{ }^{3} / \mathrm{q}=$ $6.11 \cdot 10^{-4} \mathrm{~cm}^{2} \mathrm{~s}$ and $\tan \gamma=1$ one finds that is valid between $0^{\circ} \mathrm{C}$ and $25^{\circ} \mathrm{C}$.

$$
\ell=12+0.52 \cdot \mathrm{T} \quad[\mathrm{cm}]
$$

The value of $\mathrm{h}_{\mathrm{c}}^{3} / \mathrm{q}$ is close to that found from the dependence of length on slope in the previous example.

As a final example we discuss the data presented in Fig. 8 which relates the average lengths of rillenkarren in the Serra de Tramuntana as a function of altitude above sea level, taken from: Lundberg and Gines ( 2006).

There is a clear decrease of length with altitude $h$, which can be caused by two reasons. First there is a linear relation between altitude and temperature. The up most abszissa shows the corresponding temperature given by

$$
\mathrm{T}=17-0.0065 \mathrm{H}\left({ }^{\circ} \mathrm{C}\right),(29)
$$

where the altitude $\mathrm{H}$ is in $\mathrm{m}$.

Furthermore mean annual precipitation $\mathrm{q}_{\mathrm{av}}$ is related to altitude $\mathrm{H}$ by

$$
\mathrm{q}_{\mathrm{av}}=461+0.4 \mathrm{H}[\mathrm{mm} / \text { year }](30)
$$

See upper abscissa in Fig 8.

We now assume that the actual rainfall to the rock is related to $q_{a v}$ by $q=f_{q} \cdot q_{a v}$, where $f_{q}$ is a constant.

Both $q$ and viscosity $\eta$ depend on altitude. Using eqns. $26,27,29$, and 30 one can calculate the length as a function of altitude. With $\mathrm{h}_{\mathrm{c}}^{3} / \mathrm{q}$ as a fitting parameter one obtains the curve in Fig. 8.

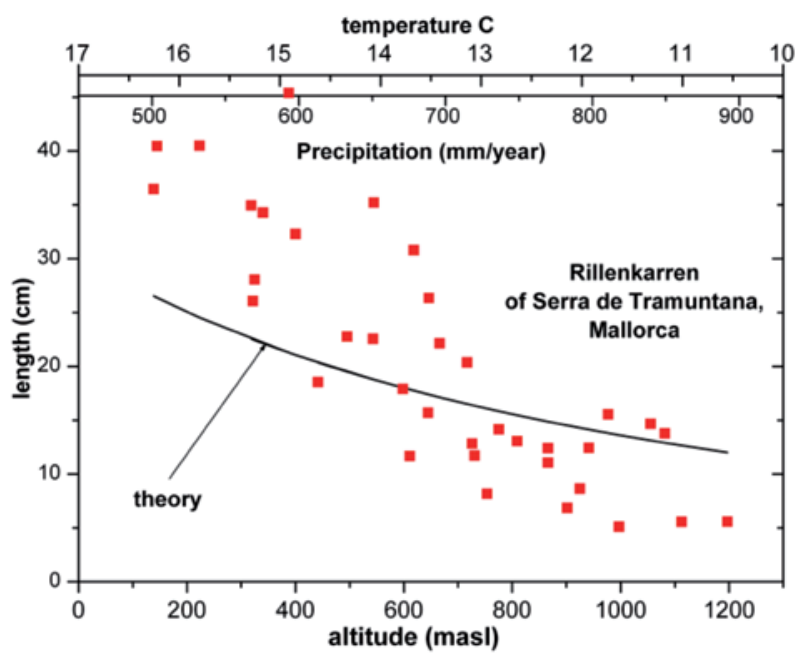

Fig. 8: Length of natural rillenkarren on limestone (Mallorca) versus altitude above sea level. From J. Lundberg and A. Gines, private communication. The curve represents the fit discussed in the text.

The curve underestimates the large lengths, but shows the general trend. Whether it is a reasonable estimation must be judged from the value of $h_{c}{ }^{3} / q(H)$. If one assumes that $1000 \mathrm{~mm} /$ year correspond to an average actual precipitation of $10 \mathrm{~mm} /$ hour one obtains $h_{c}=0.005 . \mathrm{cm}$ and correspondingly $h_{c}{ }^{3} / q(600)=6.7 \cdot 10^{-4}$ $\mathrm{cm}^{2}$ s. This value is also close to those found in the pre- 
vious examples. Assuming an average actual precipitation of $10 \mathrm{~mm} / \mathrm{h}$ dominant in the formation of karren one finds $\mathrm{h}_{\mathrm{c}}=0.0059 \mathrm{~cm}$ from the length-slope relation and $h_{c}=0.0065 \mathrm{~cm}$ from the length-temperature relation.

In all three examples we have assumed an average precipitation of about $10 \mathrm{~mm} /$ hour during the formation or rillenkarren. This is a value, which seems possible. For higher precipitation the length would be smaller and would be overprinted by lower precipitation yielding longer karren. At low precipitation rates $(1 \mathrm{~mm} /$ hour $)$ the karren become very long $(2 \mathrm{~m})$ and will form very slowly, such that they may not be detected.
In summary Glew's and Ford's idea that karren length is determined by a critical thickness $h_{c}$ of the down flowing water film can be used to explain field data. One should keep in mind that at a precipitation rate of 10 $\mathrm{mm} / \mathrm{h}$ a film thickness of $0.006 \mathrm{~cm}$ is attained after $27 \mathrm{~cm}$ on a smooth rock surface inclined by $45^{\circ}$.

We do not know at present the physical reason, why this critical thickness avoids further growth of rillenkarren. This requires experimental observations of flow rates and chemical composition of the water flowing on natural karren on limestone during rain storms of various intensities.

\section{DENUDATION RATES IN THE FIELD}

\section{GYPSUM}

Denudation rates on subaerial exposed gypsum samples have been reported by Gucchi et al (1996). In an observation station close to Triest (Italy) with a yearly rainfall of $1350 \mathrm{~mm}$ they found $0.9 \mathrm{~mm} /$ year as an average during an observation time of eight years.

At rainfall intensities of $40 \mathrm{~mm} /$ hour the solution running off the rock has a concentration of $0.5 \mathrm{c}_{\mathrm{eq}}$. At lower rainfall intensities of $4 \mathrm{~mm} /$ hour one finds $c=0.9 c_{e q}$. Therefore it is reasonable to take an average value $\mathrm{c}=$ $0.75 c_{\text {eq }}$ for all the water during one year's rainfall. From this one finds a denudation rate of $1 \mathrm{~mm} /$ year.

\section{LIMESTONE}

For dissolution under linear kinetics with a rate law

$$
\mathrm{R}=\alpha\left(\mathrm{c}_{\mathrm{eq}}-\mathrm{c}\right)
$$

the time $\mathrm{T}$, which is needed until a volume element with initial concentration zero attains concentration of $0.63 \mathrm{c}_{\mathrm{eq}}$ is given by

$$
\mathrm{T}=\mathrm{h} / \alpha
$$

For limestone with a film thickness of $0.2 \mathrm{~mm}$ one finds $\mathrm{T} 1=10^{-2} / \tilde{\alpha}_{1}=20 \mathrm{~s}$ to attain $\mathrm{c}=0.64 \mathrm{c}_{\text {app }}$. In the slower region 2, $\tilde{\alpha}_{2}=2 \cdot 10^{-5} \mathrm{cms}^{-1}$ and the time to reach $\mathrm{c}=0.63 \mathrm{c}_{\mathrm{eq}}$ is $\mathrm{T}_{2}=500 \mathrm{~s}$. Under natural rainfall flow velocities are on the order of $1 \mathrm{cms}^{-1}$. Therefore dissolution will be effective only in region 1 . Even when the water dissolved limestone in region 2 the dissolution rates were about two orders of magnitude lower. In other words, all the water, which falls to the rock surface, will leave it with concentration $\mathrm{c}_{\infty}$ derived from dissolution in region 1.

With $\tilde{\alpha}_{1}=10^{-3} \mathrm{cms}^{-1}$ one finds

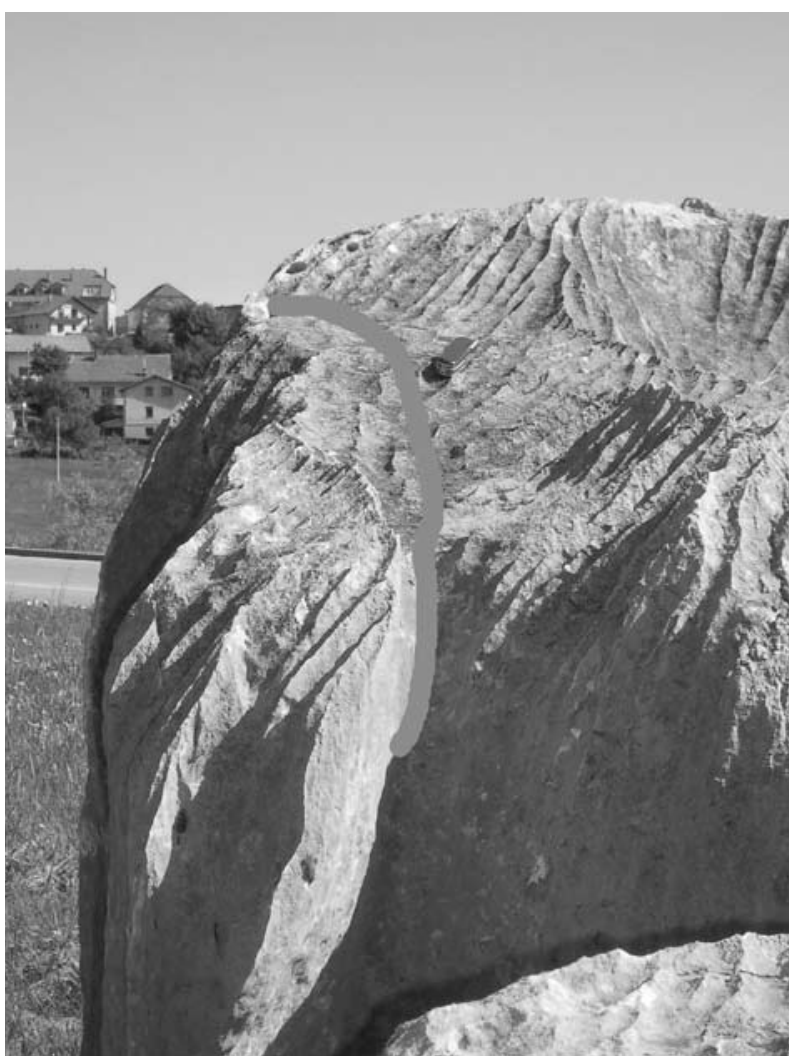

Fig. 9: Karren formation, from which water was collected. The grey line marks the flow path. The water was collected at the end of this line.

$$
\mathrm{c}_{\infty}=\frac{10^{-3}}{10^{-3}+2.8 \cdot 10^{-5} \cdot \mathrm{p} \cdot \cos \gamma} \cdot \mathrm{c}_{\mathrm{app}}
$$

where $\mathrm{p}$ is the rainfall intensity in $\mathrm{mm} / \mathrm{h}$. 
At low slope angles $(\cos \gamma \approx 1)$ and for rainfall intensities of $1 \mathrm{~mm} / \mathrm{h}, \mathrm{c}_{\infty}=0.97 \mathrm{c}_{\text {app }}=0.29 \mathrm{mmol} / \ell$. At $10 \mathrm{~mm} / \mathrm{h}$, $\mathrm{c}_{\infty}=0.24 \mathrm{mmol} / \ell$, and for extreme intensities of $40 \mathrm{~mm} / \mathrm{h}$ $\mathrm{c}_{\infty}=0.14 \mathrm{mmol} / \ell$.

Cucchi et al., (1996), by using micrometers, measured surface denudation rates on a huge number of limestone samples with slope angles of about 15 degrees in the karst of Triest. They found average dissolution rates sampled over eight years of $0.015 \pm 0.01 \mathrm{~mm} /$ year. At an average rainfall of $1350 \mathrm{~mm} /$ year in this region one needs an average run-off concentration $c_{\infty}=0.5 c_{\text {eq }}$ to explain this number. A closer inspection of the distribution of rainfall-depth distribution is therefore necessary to verify this number. Anyway, our findings support that denudation on bare rock by the dissolutional action of rainwater is caused by fast dissolution in region 1 of Fig. 2 .

We have performed a first attempt to measure concentrations of rainwater flowing from the surface of a karren formation of limestone from Lipica, Slovenia, ex- hibited in front of the Postojna cave. After two days of heavy rainfalls, cleaning the rock from dust, water was collected during a medium strong rainfall of a few millimeters/h by use of an aluminum foil attached to the rock. Fig. 9. shows the experimental situation. The water had flown on top of the formation, which exhibits only a slight inclination of about $10^{\circ}$ degree for about one meter, then down one half meter, almost vertically, where it was channelled by the foil and collected into a beaker. This flowpath is depicted by the grey line. Measures were taken to prevent dilution of the sample by rainwater dripping into it. In parallel a sample of rainwater was collected. The specific conductivities were measured in the field. The conductivity of rain water was $6 \mu \mathrm{S} / \mathrm{cm}$, whereas the water from the karren exhibited $57 \mu \mathrm{S} / \mathrm{cm}$. Analysis for calcium in the lab yielded a value of $0.25 \mathrm{mmol} / \mathrm{liter}, 38 \%$ of the saturation value of $65 \mathrm{mmol} / \mathrm{liter}$ at $10 \mathrm{C}$, the temperature during collection of the sample. This result is in good agreement to what one expects from eqn. 28 .

\section{DISCUSSION AND CONCLUSION}

We have presented some basic principles of flow dynamics of thin water films that can approximate flow on natural rock surfaces under rainfall conditions. Although these approximations are crude they can be used for realistic estimations.

To understand the formation of geomorphologic features on rock surfaces basic knowledge of the dissolution rates by flowing water sheets is needed. Water in equilibrium with the $\mathrm{p}_{\mathrm{CO}_{2}}$ of the atmosphere dissolves limestone quickly up to a concentration of $\mathrm{c}_{\text {app }} \approx 0.3 \mathrm{c}_{\text {eq }}$. For higher concentrations the dissolution rates drop rapidly. The time to reach the concentration $c_{\text {app }}$ under natural rainfall conditions is on the order of 10 seconds, sufficiently short, that all dissolution will be affected in this regime of concentrations. Even if the solution would reach concentrations higher than $c_{\text {app }}$, then dissolution rates drop to such low values that they become insignificant. We have presented experimental data, which confirm this behaviour. It is also possible to understand from these kinetics denudation rates of limestone measured in the field.

For gypsum dissolution rates are controlled by mixed kinetics of surface reactions and molecular diffusion. Therefore, the rates become dependent on the thickness of the flowing water sheet. It is possible, however, to predict denudation rates on gypsum, as obtained from field data. Furthermore experimental findings on Rillenkarren can be explained.
It should be noted that we have neglected temperature dependence and have used $20^{\circ} \mathrm{C}$ as standard. Since many of the constants used depend on temperature, however, some temperature dependence on the denudation rates is expected. In view of the many approximations this is not of high significance.

We have not addressed the issue of Rillenkarren formation. At present one may only speculate. The surface of the rocks acts to flow like a two-dimensional porous medium. In such an inhomogeneous environment channelling can occur and parallel flow paths can arise, where the flow rates are higher. For limestone then the concentration $\mathrm{c}_{\infty}$ decreases and dissolution rates correspondingly increase. In gypsum the solution is close to saturation and therefore the amount of dissolved rock is proportional to the volume of the flowing water. One therefore could imagine that Rillenkarren could only originate at rough rocks. This issue can be handled experimentally by simulating karren formation experimentally on polished and rough samples of plaster of Paris.

An object of further research should be to measure flow velocities on limestone surfaces under natural conditions in dependence of rainfall intensity, and also to take samples of the water at various locations on that surface to obtain calcium concentrations. Such experimental data could be of utmost use for a better understanding. One of the purposes of this work is to stimulate such research. 


\section{ACKNOWLEDGEMENT}

We thank Joyce Lundberg and Angel Gines for providing their field data in Figures 6, 7 and 8.

\section{REFERENCES}

Beek, W. J., \& Muttzall, K.M.K., 1975: Transport Phenomena. Wiley, London and New York.

Buhmann, D., \& Dreybrodt, W., 1985: The kinetics of calcite dissolution and precipitation in geologically relevant situations of karst areas: 1. Open system.Chemical Geology 48, 189-211.

Dreybrodt, W., 1988: Processes in Karst Systems.- Physics, Chemistry, and Geology,

Springer, Berlin and New York.

Cucchi, F., Forti, P., \& Marinetti, E., 1996: Surface degradation of carbonate rocks in the karst of Trieste. In J.J., Fornos, \& Gines, A., (editors): Karren landforms, Universitat de les Illes Balears, Palma.

Gines, A., \& Lundberg, J., 2006: Rillenkarren, private communication.

Glew, J.R., \& Ford, D.C., 1980: A Simulation Study of the development of Rillenkarren.-

Earth Surface Processes, 5, 25-36.

Jeschke, A.A., Vosbeck, K., \& Dreybrodt, W., 2001: Surface controlled dissolution rates in aqueous solutions exhibit nonlinear dissolution kinetics.- Geochimica et Cosmochimica Acta, 65, 13-20.

Kaufmann, G., \& Dreybrodt, W., 2007: Calcite dissolution kinetics in the system $\mathrm{CaCO}_{3}-\mathrm{H}_{2} \mathrm{O}-\mathrm{CO}_{2}$ at high undersaturation.- Geochimica et Cosmochimica Acta, 71 (6), 1398-1410.
Myers, T.G., 2002: Modeling laminar sheet flow over rough surfaces.- Water Resources Research, Vol. 38, No. 11: 1230 (12-1 - 12-12).

Petterson, 0., 2001: The development of a technique to measure water film thickness and the study of flow hydraulics and dissolutional characteristics on plaster of Paris rillenkarren channels, B.Sc.-Thesis, University of Bristol, School of geographical Sciences, U.K.

Phelps, H.O., 1975: Shallow laminar flows over rough granular surfaces.- J. Hydraul. Div. Am. Soc. Civ. Eng. 10 (HY3): 367-384.

Plummer, L.N., Wigley, T.M.L., \& Parkhurst, D.L., 1978: The kinetics of calcite dissolution in $\mathrm{CO}_{2}$-water systems at 5 to $60 \mathrm{C}$ and 0.0 to $1.0 \mathrm{~atm} \mathrm{CO}_{2}$.- Am. J. Sci. 278, 179-216.

Svensson, U., \& Dreybrodt, W., 1992: Dissolution kinetics of natural calcite minerals in $\mathrm{CO}_{2}$-water-systems approaching calcite equilibrium.- Chemical Geology 100, 129-34.

Usdowski, E., 1982: Reactions and equilibria in the systems $\mathrm{CO}_{2}-\mathrm{H} 2 \mathrm{O}$ and $\mathrm{CaCO}_{3}-\mathrm{CO}_{2}-\mathrm{H}_{2} \mathrm{O}(0-50 \mathrm{C})$. A review.- Jb. Miner. Abh. 144, 148-171. 
